Review

\title{
Distinguishing Health Benefits of Eicosapentaenoic and Docosahexaenoic Acids
}

\section{Fraser D. Russell * and Corinna S. Bürgin-Maunder}

Faculty of Science, Health, Education and Engineering, University of the Sunshine Coast, Maroochydore, Queensland 4556, Australia; E-Mail: CBurgin@usc.edu.au

* Author to whom correspondence should be addressed; E-Mail: frussell@usc.edu.au; Tel.: +61-7-5459-4665.

Received: 24 September 2012; in revised form: 16 October 2012 / Accepted: 31 October 2012 / Published: 13 November 2012

\begin{abstract}
Long chain omega-3 polyunsaturated fatty acids (LC $n$-3 PUFAs) are recommended for management of patients with wide-ranging chronic diseases, including coronary heart disease, rheumatoid arthritis, dementia, and depression. Increased consumption of eicosapentaenoic acid (EPA) and docosahexaenoic acid (DHA) is recommended by many health authorities to prevent (up to $0.5 \mathrm{~g} /$ day) or treat chronic disease (1.0 g/day for coronary heart disease; $1.2-4 \mathrm{~g} /$ day for elevated triglyceride levels). Recommendations for dietary intake of LC $n$-3 PUFAs are often provided for $\alpha$-linolenic acid, and for the combination of EPA and DHA. However, many studies have also reported differential effects of EPA, DHA and their metabolites in the clinic and at the laboratory bench. The aim of this article is to review studies that have identified divergent responses to EPA and DHA, and to explore reasons for these differences. In particular, we review potential contributing factors such as differential membrane incorporation, modulation of gene expression, activation of signaling pathways and metabolite formation. We suggest that there may be future opportunity to refine recommendations for intake of individual LC $n$-3 PUFAs.
\end{abstract}

Keywords: LC $n$-3 PUFAs; omega-3 fatty acids; eicosapentaenoic acid; docosahexaenoic acid; resolvin D1; differential response; omega-3 fatty acid metabolites 


\section{Recommendations for Daily Intake of $n-3$ PUFAs}

Long chain omega-3 polyunsaturated fatty acids (LC $n-3$ PUFAs) are fatty acids with a long chain (20 carbons or more), with the first double bond located after the third carbon from the methyl end. LC $n$-3 PUFAs, including eicosapentaenoic acid (EPA) and docosahexaenoic acid (DHA), have long been proposed to bestow health benefits by improving blood pressure control, alleviating symptoms of rheumatoid arthritis and depression, as well as attenuating the progression of Alzheimer's disease [1-4]. It is noteworthy that recent meta-analyses have reported no effect of LC $n$-3 PUFAs on incidence of fatal coronary heart disease and sudden death [5,6], in stark contrast to earlier trials that reported marked reductions in risk for these events [7,8]. Differences in trial design (open label versus randomized, double-blind, placebo controlled), baseline clinical management (for example, low versus high use of anti-thrombotic and anti-hypertensive medications), and absolute risk for adverse events (for example, patients with few versus many risk factors, including previous myocardial infarction, with diabetes and low use of statins), have been postulated to explain the divergent findings [9]. Dose is also an important determinant of patient outcome, where high doses only of LC n-3 PUFAs (for example, 2-4 g EPA + DHA/day) can provide cardiovascular benefit associated with serum triglyceride reduction [10]. Whilst evidence for the capacity of LC $n-3$ PUFAs to lower serum triglyceride concentration is particularly strong, improvements in patient outcome have additionally been ascribed to modulation of signaling pathways involved in inflammation and oxidative stress, improvement in endothelial function, and inhibition of platelet aggregation (see Section 2).

Although plant-derived $\alpha$-linolenic acid (ALA) is obtained from dairy products and margarines [11] and can be enzymatically converted to EPA and DHA in humans, the process is inefficient $(0.04 \%-2.84 \%)$, and restricted by high dietary intake of EPA, DHA and linoleic acid [12,13]. Whilst low delta- 6 desaturase activity in humans contributes to poor conversion of ALA to EPA and DHA [14], levels of EPA and DHA can nonetheless be increased through dietary intake of LC n-3 PUFA-enriched foods or marine oil supplements containing these fatty acids [15]. Major sources of LC $n$-3 PUFAs in the diet of developed countries are fish, red meat and poultry [11,16,17], where combinations of these foods contribute high levels (>75\% of the total intake derived from 29 different food groups) of DHA (fish and poultry), EPA (fish and red meat), and docosapentaenoic acid (DPA; red meat, poultry and fish) [11]. Many of the aforementioned benefits of LC $n-3$ PUFAs have been attributed to the intake of DHA and/or EPA.

Countries that have high dietary intake of fish, such as Japan, have populations that benefit from cardioprotective levels of LC $n$-3 PUFAs [18]. However, many populations consume amounts of LC $n$-3 PUFAs that are regarded as "adequate", avoiding problems associated with deficiency, but not enough to provide health protection. Health authorities in these countries recommend increased intake of LC $n$-3 PUFAs to provide such benefits. For example, European health authorities recommend at least 0.45-0.50 g/day EPA + DHA to maintain good health [19-21]. The mean daily intake of EPA + DHA and ALA in Australian adults is $0.175 \mathrm{~g}$ and $1.07 \mathrm{~g}$, respectively [22]. The Heart Foundation of Australia recommends a daily dietary intake of $0.5 \mathrm{~g}$ EPA + DHA plus $2.0 \mathrm{~g}$ ALA to lower the risk of coronary heart disease, $1.0 \mathrm{~g}$ EPA + DHA plus $2.0 \mathrm{~g}$ ALA for patients with documented coronary heart disease, and 1.2-4.0 g EPA + DHA for patients with elevated serum triglyceride levels [22]. Table 1 collates recommendations for dietary intake of LC $n-3$ PUFAs by selected National and International 
health and government organizations. Most of these organizations have issued recommendations for combined intake of EPA and DHA, but do not provide advice for the ratio of EPA to DHA. The French Agency for Food, Environmental and Occupational Health \& Safety [20] is a notable exception, providing separate recommendations for dietary intake of EPA and DHA (Table 1). Following the American Psychiatric Association recommendation of $1.0 \mathrm{~g} / \mathrm{day}$ DHA+EPA for the treatment of affective disorders ([23], Table 1), McNamara [24] proposed a 2:1 ratio of EPA:DHA for optimal patient management.

Differential associations for cell membrane EPA and DHA levels and resting state electroencephalographic (EEG) activity have been reported. DHA was associated with fast frequency EEG activity while EPA was associated with slow frequency EEG activity in 46 adolescent boys with attention deficit hyperactivity disorder [25]. Not surprisingly, the health benefits of the LC- $n-3$ PUFAs have often been ascribed to particular types of LC- $n$-3 PUFAs. For example, studies have reported blood pressure lowering effects of DHA but not EPA [26,27], while EPA has been reported to be more efficacious than DHA in reducing platelet activation [28,29]. The differential response to EPA and DHA suggests that an opportunity might exist to customize advice for the types or ratios of LC $n-3$ PUFAs to be used in the treatment of particular conditions or diseases. The implementation of such a strategy is certainly achievable, with a plethora of commercially available dietary marine oil supplements of defined LC $n$-3 PUFA composition [30]. For example, EPAX 5510 TG/N is an EPA-rich oil (EPA/DHA ratio of 5:1), while EPAX 1050 TG/N is a DHA-rich oil (EPA/DHA ratio of 1:5) [31]. Salunkhe et al. [32] recently identified a marine bacterial isolate that produces high concentrations of EPA ( $60 \%$ of total fatty acid content) at $30{ }^{\circ} \mathrm{C}$, with no detectable production of DHA. The strategy may also be achievable by considering the dietary intake of fish and meat sources. For example, of fish high in LC $n$-3 PUFAs content, the ratio of EPA:DHA can range from $\sim 1: 2$ for Atlantic Salmon and Ocean Trout to $\sim 1: 30$ for Snook [33].

The purpose of this review is to examine studies that have reported heterogeneity with respect to effects of the LC $n$-3 PUFAs, chiefly EPA and DHA, and to examine some of the reasons for these differential responses. In particular, we review the impact of differential metabolism, membrane incorporation, modulation of gene expression, and activation of signaling pathways for EPA and DHA. 
Table 1. Recommendations for Long chain omega-3 polyunsaturated fatty acids (LC $n-3$ PUFA) intake obtained from selected national and international health and government organizations.

\begin{tabular}{|c|c|c|c|}
\hline Health Organization & Country & Recommendation & Ref. \\
\hline National Heart Foundation & Australia & $\begin{array}{l}0.5 \mathrm{~g} / \text { day EPA + DHA plus } 2 \mathrm{~g} / \text { day ALA to lower the risk of coronary heart disease; } 1.0 \mathrm{~g} / \mathrm{day} \text { EPA + DHA plus } 2 \mathrm{~g} / \mathrm{day} \text { ALA } \\
\text { for patients with documented coronary heart disease; } 1.2-4.0 \mathrm{~g} / \text { day EPA + DHA for patients with elevated serum triglyceride } \\
\text { levels. }\end{array}$ & [22] \\
\hline American Heart Association & USA & $\begin{array}{l}\geq 2 \text { fish meals/week plus oils rich in ALA in subjects without coronary heart disease; } 1.0 \mathrm{~g} / \text { day EPA + DHA for patients with } \\
\text { documented coronary heart disease; } 2.0-4.0 \mathrm{~g} / \text { day EPA + DHA for patients with elevated serum triglyceride levels. }\end{array}$ & {$[34]$} \\
\hline World Health Organization & International & $0.2-0.5 \mathrm{~g} / \mathrm{day} \mathrm{EPA}+\mathrm{DHA}$ to prevent coronary heart disease and ischemic stroke. & [35] \\
\hline American Psychiatric Association & USA & $1.0 \mathrm{~g} /$ day EPA + DHA for treatment of affective disorders. & [23] \\
\hline $\begin{array}{l}\text { 1. National Health and Medical Research } \\
\text { Council. 2. The Cancer Council Australia. }\end{array}$ & $\begin{array}{l}\text { 1. Australia \& } \\
\text { New Zealand. } \\
\text { 2. Australia }\end{array}$ & $\begin{array}{l}\text { Adequate Intake for EPA + DHA + DPA: } 0.09 \mathrm{~g} / \text { day (women } \geq 19 \text { years), } 0.16 \mathrm{~g} / \text { day (men } \geq 19 \text { years). ALA: } 0.8 \mathrm{~g} / \text { day (women } \\
\geq 19 \text { years), } 1.3 \mathrm{~g} / \text { day (men } \geq 19 \text { years). Intake of } \mathrm{EPA}+\mathrm{DHA}+\mathrm{DPA} \text { to reduce risk of chronic disease: } 0.43 \mathrm{~g} / \text { day (women), } \\
0.61 \mathrm{~g} / \text { day (men). }\end{array}$ & {$[36,37]$} \\
\hline $\begin{array}{l}\text { Scientific Advisory Committee on } \\
\text { Nutrition }\end{array}$ & UK & General nutrition, at least $0.45 \mathrm{~g} /$ day LC $n-3$ PUFAs. & [19] \\
\hline $\begin{array}{l}\text { French Agency for Food, Environmental } \\
\text { and Occupational Health \& Safety }\end{array}$ & France & General nutrition, $0.25 \mathrm{~g} /$ day EPA; $0.25 \mathrm{~g} /$ day DHA, $1 \%$ of energy intake ALA. & [20] \\
\hline Health Council of the Netherlands & Netherlands & General nutrition, $0.45 \mathrm{~g} /$ day fish fatty acids. & {$[21]$} \\
\hline $\begin{array}{l}\text { International Society for the Study of Fatty } \\
\text { Acids and Lipids }\end{array}$ & International & Cardiovascular health, $\geq 0.5 \mathrm{~g} /$ day EPA + DHA. General nutrition, $0.7 \%$ of energy intake ALA. & [38] \\
\hline
\end{tabular}




\section{Evidence for Differential Responses to EPA and DHA}

Although EPA and DHA are both long chain polyunsaturated fatty acids (EPA, C20:5n3; DHA, $\mathrm{C} 22: 6 \mathrm{n} 3)$, the molecules are often reported to produce biochemical and physiological responses that are qualitatively and quantitatively different to each other. Table 2 provides a non-exhaustive overview of studies that report differential effects of EPA and DHA, and their metabolites. Each individual study represented in Table 2 was internally controlled, thus allowing direct comparisons of responses to the fatty acids under identical experimental conditions. This is an important point, since differences in experimental design between studies have sometimes led to inconsistent conclusions in regard to the effects of the LC $n-3$ PUFAs. When considering the blood pressure lowering effects of LC $n$-3 PUFAs for example, the reader needs to be cognisant of the effects of dose and duration of treatment, baseline characteristics of the subject for dietary intake of LC $n-3$ PUFAs and blood pressure, subject age, co-morbidities, and use of anti-hypertensive medications. It is nonetheless noteworthy that several studies in Table 2 reported response, and/or lack of response that was based on the examination of a single concentration of the LC $n$-3 PUFAs. In those studies it is possible that information obtained from construction of full dose-response curves to EPA and DHA might have shown the same qualitative response, albeit with different potencies and/or efficacies. For example, Yusufi et al. [39] reported an inhibitory effect of low concentration $(10 \mu \mathrm{M})$ DHA, but not EPA on EGF-stimulated mitogenesis in mesangial cells. However, an inhibitory effect of EPA, quantitatively similar to that of DHA, was revealed when the LC $n$-3 PUFAs were used at a 10-fold higher concentration [39]. Similarly, studies that rely on single time-points for measurement of response may not capture changes that occur after short-term-, or more typically after long-term treatment regimens. This point is exemplified by the early incorporation (2-14 days) of EPA, but not DHA into erythrocyte membranes, with DHA incorporation occurring later (14-28 days) [40].

Interestingly, there are instances where EPA and DHA produce opposite responses, for example in the regulation of c-abl proto-oncogene, glutathione $S$-transferase A1, and breast cancer type 2 susceptibility protein gene expression [41], modulation of pulse pressure in a rat model of hypertension [27], and changes to resting heart rate in healthy human subjects [42] (Table 2). These examples suggest fundamental differences in the mechanism of action for the different LC $n-3$ PUFAs. Discussion of factors likely to contribute to the divergent responses to individual LC $n-3$ PUFAs is reported in Section 3. 
Table 2. Summary of selected studies identifying differential effects of docosahexaenoic acid (DHA), eicosapentaenoic acid (EPA) and their metabolites.

\begin{tabular}{|c|c|c|c|}
\hline Gene expression & Study & Summary of differences & Ref. \\
\hline $\begin{array}{l}\text { Genes regulating } \\
\text { inflammation, the cell } \\
\text { cycle, apoptosis }\end{array}$ & $\begin{array}{c}\text { Jurkat T cells, } 12.5 \mu \mathrm{M} \text { DHA }(n=3) \text { or EPA }(n=3) \text { for } 1 \text { day (compared } \\
\text { to untreated cells). }\end{array}$ & $\begin{array}{c}\text { CD27 ligand: DHA no change, EPA } \uparrow . \\
\text { Fibronectin I: DHA } \uparrow, \text { EPA no change. } \\
\text { Insulin receptor: DHA } \uparrow, \text { EPA no change. } \\
\text { Microsomal Glutathione } S \text {-transferase I: DHA no change, EPA } \downarrow \text {. } \\
\text { Cyclin-dependent kinase } 4 \text { inhibitor } 2 \text { : DHA } \uparrow \text {, EPA no change. } \\
\text { Phospholipase } \mathrm{A}_{2} \text { : DHA } \uparrow, \text { EPA no change. } \\
\text { c-abl proto-oncogene: DHA } \uparrow, \text { EPA } \downarrow \text {. } \\
\text { Glutathione } S \text {-transferase A1: DHA } \uparrow, \text { EPA } \downarrow \text {. } \\
\text { Breast cancer type } 2 \text { susceptibility protein: DHA } \uparrow, \text { EPA } \downarrow \text {. }\end{array}$ & [41] \\
\hline Cytokine mRNA expression & $\begin{array}{l}\text { Lipopolysaccharide-stimulated human THP-1 macrophages. } \\
100 \mu \mathrm{M} \text { DHA }(n=5-6) \text { or EPA }(n=5-6) \text { for } 2 \text { days. }\end{array}$ & 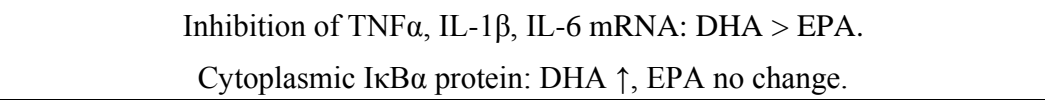 & [43] \\
\hline $\begin{array}{l}\text { UDP-glucuronosyl } \\
\text { transferase IAI (UGTIAI) } \\
\text { mRNA expression } \\
\end{array}$ & $\begin{array}{l}\text { Human hepatoma HepG2 cells, } 50 \mu \mathrm{M} \text { DHA }(n=3) \text { or EPA }(n=3) \text { for } \\
1 \text { day (compared to vehicle). Some cells co-treated with } 10 \mu \mathrm{M} \text { vitamin } \mathrm{E} \text {. }\end{array}$ & $\begin{array}{c}\text { UGTIAI mRNA: DHA no change (but } \downarrow \text { with vitamin E), EPA } \downarrow \text { (but } \uparrow \text { to control } \\
\text { levels with vitamin E). }\end{array}$ & {$[44]$} \\
\hline $\begin{array}{l}\text { Cannabinoid receptor } 2 \\
\text { (CB2) and NAPE-PLD } \\
\text { mRNA expression }\end{array}$ & $\begin{array}{l}\text { MC3T3-E1 osteoblast-like cells. } \\
10 \mu \mathrm{M} \text { DHA }(n=3-4) \text { or EPA }(n=3-4) \text { for } 3 \text { days (compared to vehicle). }\end{array}$ & $\begin{array}{l}\text { CB2 mRNA: DHA no change, EPA } \downarrow \\
\text { NAPE-PLD mRNA: DHA no change, EPA } \downarrow\end{array}$ & {$[45]$} \\
\hline $\begin{array}{l}\text { PPAR } \gamma \text { and adiponectin } \\
\text { mRNA }\end{array}$ & $\begin{array}{l}\text { 3T3-L1 adipocytes. } \\
125 \mu \mathrm{M} \text { DHA }(n=3) \text { or EPA }(n=3) \text { for } 1 \text { day (compared to vehicle). }\end{array}$ & $\begin{array}{l}\text { PPAR } \gamma \text { mRNA: DHA } \uparrow, \text { EPA no change. } \\
\text { Adiponectin mRNA: DHA } \uparrow, \text { EPA no change. }\end{array}$ & [46] \\
\hline CYP2J2 mRNA expression & $\begin{array}{l}\text { Human umbilical vein endothelial cells. } \\
1,10 \mu \mathrm{M} \text { DHA }(n=5) \text { or EPA }(n=5) \text { for } 1 \text { day (compared to vehicle). }\end{array}$ & CYP2J2 mRNA: DHA no change, EPA $\uparrow$. & {$[47]$} \\
\hline
\end{tabular}


Table 2. Cont

\begin{tabular}{|c|c|c|c|}
\hline Cellular Response & Study & Summary of differences & Ref. \\
\hline $\begin{array}{l}\text { Serum lipoproteins and } \\
\text { LDL particle size }\end{array}$ & $\begin{array}{l}\text { Overweight, non-smoking, mildly hyperlipidemic men. } \\
\text { DB, RD, PC. } 4 \text { g/day DHA }(n=17) \text { or EPA }(n=19) \text { for } 6 \text { weeks. }\end{array}$ & $\begin{array}{l}\mathrm{HDL}_{2} \text {-cholesterol: DHA } \uparrow, \text { EPA no change. } \\
\mathrm{HDL}_{3} \text {-cholesterol: DHA no change, EPA } \downarrow \text {. } \\
\text { LDL particle size: DHA } \uparrow, \text { EPA: no change. }\end{array}$ & [48] \\
\hline Serum lipoproteins & $\begin{array}{l}\text { Non-smoking, healthy men. } \\
\text { DB, RD, PC. } 3.6 \text { g/day DHA }(n=72), 3.8 \mathrm{~g} / \text { day EPA }(n=75) \text { for } 7 \text { weeks. }\end{array}$ & $\begin{array}{c}\text { HDL-cholesterol: DHA } \uparrow, \text { EPA no change. } \\
\text { Apolipoprotein A-I: DHA no change, EPA } \downarrow \text {. } \\
\text { Total cholesterol: DHA no change, EPA } \downarrow \text {. } \\
\text { Accumulation into serum phospholipids: DHA > EPA. } \\
\Delta 6 \text {-Desaturation activity: DHA } \downarrow, \text { EPA no change. } \\
\Delta 5 \text {-Desaturation activity: DHA } \downarrow, \text { EPA } \uparrow .\end{array}$ & [49] \\
\hline Serum lipoproteins & $\begin{array}{l}\text { Non-smoking normolipidemic men and women. } \\
\text { B, RD. } 2.3 \mathrm{~g} / \text { day DHA }(n=25) \text { or } 2.2 \mathrm{~g} / \text { day EPA }(n=25) \text { for } 6 \text { weeks. }\end{array}$ & HDL cholesterol: DHA $\uparrow$, EPA no change. & {$[50]$} \\
\hline LDL particle size & $\begin{array}{l}\text { Non-smoking hypertensive diabetic men and postmenopausal women. } \\
\text { DB, RD, PC. } 4 \text { g/day DHA }(n=18) \text { or EPA }(n=17) \text { for } 6 \text { weeks. }\end{array}$ & LDL particle size: DHA $\uparrow$, EPA no change. & [51] \\
\hline Triglyceride formation & $\begin{array}{l}\text { Rat liver microsomes. } \\
\text { 5-20 } \mu \mathrm{M} \text { DHA-CoA }(n=4) \text { or EPA-CoA }(n=4) \text { for } 10 \mathrm{~min} .\end{array}$ & Triglyceride formation: DHA-CoA > EPA-CoA. & {$[52]$} \\
\hline Lipid peroxidation & $\begin{array}{l}\text { Rat C6 Glioblastoma cells. } \\
100 \mu \mathrm{M} \mathrm{DHA}(n=3) \text { or EPA }(n=3) \text { for } 1-3 \text { days. }\end{array}$ & Thiobarbituric acid production: DHA > EPA. & [53] \\
\hline Endothelial cell migration & $\begin{array}{l}\text { Cultured H5V endothelial cells. } \\
100 \mu \mathrm{M} \text { DHA }(n=3) \text { or EPA }(n=3) \text { for } 24 \mathrm{~h} .\end{array}$ & Endothelial cell migration: DHA no change, EPA $\downarrow$. & [54] \\
\hline $\begin{array}{l}\text { Enzyme activity and } \\
\text { membrane fluidity }\end{array}$ & $\begin{array}{l}\text { Human cultured foreskin fibroblasts. } \\
50 \mu \mathrm{M} \text { DHA ( } n=6 \text {, membrane fluidity; } n=9 \text { enzyme activity) or } \\
\text { EPA }(n=6, \text { membrane fluidity; } n=9 \text { enzyme activity) for } 4 \text { days. }\end{array}$ & $\begin{array}{l}\text { 5'-nucleotidase activity: DHA } \uparrow, \text { EPA no change. } \\
\text { Adenylate cyclase activity: DHA } \uparrow, \text { EPA no change. } \\
\text { Fluorescence anisotropy: DHA } \uparrow, \text { EPA no change. }\end{array}$ & {$[55]$} \\
\hline Mitogen signaling pathways & $\begin{array}{l}\text { Jurkat T cells transfected with RasGRP. } \\
10 \mu \mathrm{M} \text { DHA }(n=6) \text { or EPA }(n=6) \text { for } 3 \mathrm{~h} \text {. }\end{array}$ & $\begin{array}{l}\text { Potentiation of PMA-stimulated ERK1/2 activity: DHA } \uparrow, \text { EPA no change *. } \\
* \text { Result likely linked to differential incorporation of the LC } n \text {-3 PUFAs into } \\
\text { diacylglycerol and not different affinities of the phospholipids for RasGRP. }\end{array}$ & {$[56]$} \\
\hline
\end{tabular}


Table 2. Cont

\begin{tabular}{|c|c|c|c|}
\hline $\begin{array}{l}\text { Collagen-stimulated } \\
\text { production of platelet } \\
\text { thromboxane }\end{array}$ & $\begin{array}{l}\text { Non-smoking men and postmenopausal women with type } 2 \text { diabetes } \\
\text { mellitus. } \\
\text { DB, RD, PC. } 4 \text { g/day DHA }(n=10) \text { or EPA }(n=11) \text { for } 6 \text { weeks. }\end{array}$ & Platelet thromboxane levels: DHA $\downarrow$, EPA no change. & {$[57]$} \\
\hline Platelet aggregation & $\begin{array}{l}\text { Healthy men and women. } \\
1 \mu \mathrm{M} \text { DHA }(n=42) \text { or EPA }(n=42) \text { for } 6 \text { min. Healthy men; } 1 \mu \mathrm{M} \text { DHA } \\
(n=20) \text { or EPA }(n=20) \text { for } 6 \text { min (compared to ethanol control). }\end{array}$ & $\begin{array}{l}\text { Aggregation to collagen; men and women: EPA } \downarrow>\text { DHA } \downarrow \text {. } \\
\text { Aggregation to collagen; men only: EPA } \downarrow>\text { DHA } \downarrow\end{array}$ & {$[29]$} \\
\hline Platelet aggregation & $\begin{array}{l}\text { Human platelets. } \\
100 \mu \mathrm{M} 4(R S)-4-\mathrm{F}_{4 \mathrm{t}}-\mathrm{NeuroP} \text { or } 15-\mathrm{F}_{3 \mathrm{t}} \text {-IsoP for } 5 \text { min prior to } \mathrm{U} 46619 \text {. }\end{array}$ & $\begin{array}{c}\text { Reversible aggregation to } \mathrm{U} 46619: 4(R S)-4-\mathrm{F}_{4 t}-\mathrm{NeuroP} \text { no change, } 15-\mathrm{F}_{3 \mathrm{t}} \text {-IsoP } \downarrow \\
\text { Note: } 4 \text { (RS)-4- } F_{4 t}-\text { NeuroP is a product derived from DHA; 15- } F_{3 t} \text {-IsoP is a } \\
\text { product derived from EPA. }\end{array}$ & {$[58]$} \\
\hline $\begin{array}{l}\text { Mean platelet volume and } \\
\text { platelet count }\end{array}$ & $\begin{array}{l}\text { Healthy men and women. } \\
\text { RD, PC. } 4 \text { g/day DHA }(n=12) \text { or EPA }(n=10) \text { for } 4 \text { weeks. }\end{array}$ & $\begin{array}{c}\text { Mean platelet volume: DHA no change, EPA } \downarrow \\
\text { Platelet count: DHA no change, EPA } \uparrow . \\
\end{array}$ & {$[28]$} \\
\hline Reactive oxygen species & $\begin{array}{l}\text { Goat cultured neutrophils. } \\
25-200 \mu \mathrm{M} \text { DHA }(n=6) \text { or EPA }(n=6) \text { for } 0.5-2 \mathrm{~h} \text {. }\end{array}$ & $\begin{array}{l}\text { Cytochrome } \mathrm{C} \text { activity in resting neutrophils: DHA } \downarrow \text {, EPA no change }(0.5 \mathrm{~h} \\
\text { treatment). } \\
\text { Cytochrome } \mathrm{C} \text { activity in PMA-stimulated neutrophils: DHA } \downarrow>\text { EPA } \downarrow \text {. }\end{array}$ & [59] \\
\hline iNOS protein expression & $\begin{array}{l}\text { Mouse RAW264 macrophages. } \\
60 \mu \mathrm{M} \text { DHA }(n=3) \text { or EPA }(n=3) \text { for } 1 \text { day, then stimulated IFN- } \gamma \text { and } \\
\text { LPS for } 12 \mathrm{~h} \text { (compared to untreated, stimulated cells). }\end{array}$ & iNOS/actin protein: DHA $\downarrow$, EPA no change. & {$[60]$} \\
\hline $\begin{array}{l}\mathrm{Ca}^{2+} \text {-induced opening of } \\
\text { MPTP }\end{array}$ & $\begin{array}{l}\text { Cardiac mitochondria from male Wistar rats. } \\
\text { B. } 2.5 \% \text { caloric intake DHA }(n=8-9) \text { or EPA }(n=8-9) \text {. }\end{array}$ & MPTP opening: DHA $\downarrow$, EPA no change. & {$[61]$} \\
\hline
\end{tabular}


Table 2. Cont

\begin{tabular}{|c|c|c|c|}
\hline In vivo Response & Study & Summary of differences & Ref \\
\hline $\begin{array}{l}\text { Ischaemia-induced cardiac } \\
\text { arrhythmias (SHR) }\end{array}$ & $\begin{array}{l}\text { Spontaneously hypertensive rats. } \\
0.5 \% \mathrm{w} / \mathrm{w} \text { in the diet, up to } 450 \mathrm{mg} / \mathrm{kg} / \text { day; DHA }(n=10) \text { or EPA }(n=10) \\
\text { for } 5 \text { weeks. }\end{array}$ & Ischaemia-induced cardiac arrhythmias: DHA $\downarrow$, EPA no change. & {$[62]$} \\
\hline $\begin{array}{l}\text { Blood pressure and } \\
\text { thromboxane-like aortic } \\
\text { constriction (SHR) }\end{array}$ & $\begin{array}{l}\begin{array}{l}\text { Spontaneously hypertensive rats during the development phase of } \\
\text { hypertension. }\end{array} \\
\text { Blood pressure: } 4.5 \% \text { w/w in the diet; DHA }(n=8) \text { or EPA }(n=8) \text { for } \\
12 \text { weeks. } \\
\text { Aortic constriction: } 4.5 \% \text { w/w in the diet; DHA }(n=5) \text { or EPA }(n=5) \text { for } \\
12 \text { weeks. }\end{array}$ & $\begin{array}{c}\text { Blood pressure: DHA } \downarrow>\text { EPA } \downarrow \text {. } \\
\text { Aortic constriction: DHA } \downarrow>\text { EPA } \downarrow\end{array}$ & {$[62]$} \\
\hline $\begin{array}{l}\text { Salt-loading induced } \\
\text { proteinuria (SHR) }\end{array}$ & $\begin{array}{l}\text { Salt-loaded, stroke-prone spontaneously hypertensive rats with established } \\
\text { hypertension. } \\
4.5 \% \text { w/w in the diet; DHA }(n=7) \text { or EPA }(n=8) \text { for } 6,9 \text { and } 12 \text { weeks. }\end{array}$ & Proteinuria: DHA $\downarrow$, EPA no change. & {$[62]$} \\
\hline $\begin{array}{l}\text { Forearm blood flow } \\
\qquad \text { (Human) }\end{array}$ & $\begin{array}{l}\text { Overweight, non-smoking, mildly hyperlipidemic men. } \\
\mathrm{DB}, \mathrm{RD}, \mathrm{PC} .4 \mathrm{~g} / \text { day DHA }(n=13) \text { or EPA }(n=13) \text { for } 6 \text { weeks. }\end{array}$ & $\begin{array}{l}\text { Forearm blood flow: DHA } \uparrow, \text { EPA no change. } \\
\text { Noradrenaline-mediated constriction of forearm microcirculation: DHA } \downarrow \text {, } \\
\text { EPA no change. }\end{array}$ & {$[63]$} \\
\hline $\begin{array}{l}\text { Blood pressure and Heart } \\
\text { rate (Human) }\end{array}$ & $\begin{array}{l}\text { Overweight, non-smoking, mildly hyperlipidemic men. } \\
\text { DB, RD, PC. } 4 \text { g/day DHA }(n=17) \text { or EPA }(n=19) \text { for } 6 \text { weeks. }\end{array}$ & $\begin{array}{l}\text { Mean } 24 \mathrm{~h} \text { SBP: DHA } \downarrow \text {, EPA no change. } \\
\text { Mean } 24 \text { h DBP: DHA } \downarrow \text {, EPA no change. } \\
\text { Mean day SBP: DHA } \downarrow \text {, EPA no change. } \\
\text { Mean day DBP: DHA } \downarrow \text {, EPA no change. } \\
\text { Mean } 24 \text { h HR: DBP: DHA } \downarrow \text {, EPA no change. } \\
\text { Mean day HR: DBP: DHA } \downarrow \text {, EPA no change. } \\
\text { Mean night HR: DBP: DHA } \downarrow \text {, EPA no change. }\end{array}$ & {$[26]$} \\
\hline
\end{tabular}


Table 2. Cont.

Blood pressure and QT interval (male SHR)
Spontaneously hypertensive rats.

$240 \mathrm{mg} /$ day DHA $(n=6)$ or EPA $(n=6)$ for 8 weeks compared to normal fat diet.
Day SBP: DHA $\downarrow$, EPA no change.

Night SBP: DHA $\downarrow$, EPA no change.

Day pulse pressure: DHA $\downarrow$, EPA $\uparrow$.

Night pulse pressure: DHA $\downarrow$, EPA $\uparrow$.

Day QT interval: DHA $\downarrow$, EPA no change.

Night QT interval: DHA $\downarrow$, EPA no change.

Non-smoking, healthy men.

Heart rate

DB, RD, PC. $3.6 \mathrm{~g} /$ day DHA $(n=72)$ or $3.8 \mathrm{~g} /$ day EPA $(n=75)$ for 7

Resting HR: DHA $\downarrow$, EPA $\uparrow$.

[42]

weeks (compared to control)

Pre-contracted rat isolated aorta (untreated).

Aortic contraction: 4(RS)-4- $\mathrm{F}_{4 \mathrm{t}}-\mathrm{NeuroP}$ no change, $15-\mathrm{F}_{3 \mathrm{t}}-\mathrm{IsoP} \uparrow$.

\begin{tabular}{|c|c|c|}
\hline Vascular tension (Rat) & $\begin{array}{c}1 \mathrm{nM}-100 \mu \mathrm{M} 4(R S)-4-\mathrm{F}_{4 \mathrm{t}}-\mathrm{NeuroP}(n=4) \text { or } 15-\mathrm{F}_{3 \mathrm{t}} \mathrm{-IsoP}(n=4) \\
\text { dose-response curves. }\end{array}$ & $\begin{array}{c}\text { Note: } 4(\mathrm{RS})-4-F_{4 t} \text { NeuroP is a product derived from } D H A ; 15-F_{3 t}-I \text { soP is a } \\
\text { product derived from EPA. }\end{array}$ \\
\hline $\begin{array}{l}\text { Antidepressant effect } \\
\text { (Human) }\end{array}$ & $\begin{array}{l}\text { Meta analysis, patients with depressive symptoms. } \\
\text { DB, RD, PC. } 28 \text { studies. }\end{array}$ & Treatment of depression: EPA > DHA \\
\hline $\begin{array}{l}\text { Alzheimer disease (AD; } \\
\text { Human) }\end{array}$ & $\begin{array}{l}815 \text { subjects unaffected by AD; } 65-94 \text { years. Analysis of fish consumption } \\
\text { using food frequency questionnaire; follow-up at } 3.9 \text { years. }\end{array}$ & Risk AD: DHA $\downarrow$, EPA no change. \\
\hline
\end{tabular}

$\downarrow$, Effect of the fatty acid is to decrease; $\uparrow$, Effect of the fatty acid is to increase; B, Blinded; DB, Double-blind; RD, Randomized design; PC, Placebo controlled; SHR, spontaneously hypertensive rats; HDL, high density lipoprotein; LDL, low density lipoprotein; DHA, docosahexaenoic acid; EPA, eicosapentaenoic acid, PMA, phorbol 12-myristate 13-acetate, NAPE-PLD, $N$-acyl phosphatidylethanolamine-selective phospholipase D; MCP-1, monocyte chemotactic protein-1, MPTP, mitochondrial permeability transition pore. 


\section{Factors Contributing to Differential Responses to EPA and DHA}

\subsection{Regulation of Transcription Factors}

LC n-3 PUFAs regulate gene transcription by binding to a variety of nuclear receptors, including the retinoid-activated nuclear receptor, RXR $\beta$ [64] (via association with the brain fatty acid-binding protein-7 transporter [65]), and peroxisome proliferator-activated receptor (PPAR) [66,67]. In 3T3-L1 adipocytes, $125 \mu \mathrm{M}$ DHA upregulated PPAR $\gamma$ mRNA expression levels while $125 \mu \mathrm{M}$ EPA was without effect [46]. PPAR $\gamma$ is a transcription factor for the adiponectin gene, and activation of PPAR $\gamma$ leads to increased synthesis of adiponectin. DHA stimulated secretion of greater amounts of adiponectin from adipocytes than EPA, and only the DHA response was blocked by an antagonist of PPAR $\gamma$ [46]. The authors concluded that there may be independent actions of EPA and DHA on PPAR $\gamma /$ adiponectin signaling in adipocytes [46]. The selectivity of DHA over EPA for PPAR $\gamma$ activation may not apply to all cell types, with evidence for stimulation of PPAR $\gamma$ activity by both EPA and DHA in human kidney-2 (HK-2) cells [68], and by EPA in human umbilical vein endothelial cells [47]. It is possible that differential effects of the LC $n$-3 PUFAs may be caused by metabolism of the LC n-3 PUFA to its metabolites. A number of oxidation products of DHA were found to be more potent activators of PPAR $\gamma$ than DHA [69,70], although metabolites resolvin D1 and resolvin E1 were without effect [71]. It is not yet known whether EPA and metabolites of EPA have differential activity at PPAR. The contribution of LC $n$-3 PUFA metabolites to differential responses observed for EPA and DHA are discussed in Section 3.4.

In addition to the direct effects of EPA and DHA on transcription factors, these LC $n-3$ PUFAs also indirectly modulate transcription factors. For example, LC $n-3$ PUFAs inhibit activity of the transcription factor, nuclear factor kappa $\mathrm{B}(\mathrm{NF \kappa B})$ by attenuating phosphorylation and degradation of the inhibitory factor, IкB- $\alpha$ (reported for EPA [72]), and by inhibiting the recruitment of toll-like receptor 4 to lipid rafts (reported for DHA [73]). Although $100 \mu \mathrm{M}$ DHA was more effective than $100 \mu \mathrm{M}$ EPA in retaining I $\mathrm{KB}-\alpha$ in the cytosol of lipopolysaccharide (LPS)-stimulated macrophages, EPA and DHA were equally effective at inhibiting LPS-stimulated NFkB/DNA binding activity [43].

\subsection{Receptor-Mediated Effects of EPA and DHA}

Free fatty acids were identified as endogenous ligands for the orphan G-protein coupled receptor, GPR120 following extensive ligand-binding screening [74]. GPR120 is expressed in gastrointestinal epithelial cells [74,75], and in macrophages [76], and its activation by LC $n-3$ PUFAs leads to secretion of glucagon-like peptide-1 from epithelial cells [74,77] and anti-inflammatory effects in macrophages [76]. Recent findings revealed short and long isoforms of GPR120, both of which were responsive to free fatty acids [78]. Although differential maximal efficacies for phosphorylation of these isoforms was reported in HEK293 cells exposed to $\alpha$-linolenic acid and DHA, a comparison of EPA and DHA-mediated receptor phosphorylation was not made [78]. Nonetheless, it was speculated that the length and degree of saturation of the fatty acids may affect efficacy [78], raising the possibility that differences in efficacy might also be observed for EPA ( 20 carbons, 5 double bonds) and DHA (22 carbons, 6 double bonds). Whilst further studies are required to test this hypothesis, differences in amplitude of response to EPA and DHA have been reported previously. For example, 
serum response element-luciferase (SRE-luc) activity in HEK293 cells expressing GPR120 and the SRE-luc promoter appeared to be greater for cells treated with DHA than EPA [76]. Furthermore, secretion of glucagon-like peptide-1 from mouse colon was significantly elevated after intracolonic administration of DHA, but not EPA [77]. It is thus possible that the above interactions of EPA and DHA with GPR120 could in part explain the greater efficacy of DHA compared to EPA for the inhibition of release of pro-inflammatory cytokines from human macrophages [43] (Table 2). In that study, a single, high concentration of EPA and DHA was used $(100 \mu \mathrm{M})$, and this was therefore likely to produce a maximal response (see [76]). Interestingly, potency does not appear to be different for EPA and DHA at GPR120. Potency of EPA and DHA for stimulation of calcium mobilization in HEK293 cells expressing GPR120, and promoter activity in HEK293 cells expressing GPR120 and SRE-luc promoter, were similar [74,76].

\subsection{Incorporation of EPA and DHA into Phospholipids}

Glycerophospholipids (phospholipids) are the main component of the cell membrane, and include structures such as phosphatidylcholine and phosphatidylserine. Dietary intake of EPA and DHA increases the LC $n-3$ PUFA content of phospholipids with an associated reduction in arachidonic acid levels $[49,79,80]$. The source of LC $n$-3 PUFAs may affect the extent to which EPA and DHA are incorporated into phospholipids. A recent study recruited healthy, young (20-50 years) men and compared incorporation of fish oil (EPA and DHA as re-esterified triglycerides or ethyl esters, with no free fatty acids) and krill oil-derived EPA and DHA (mainly bound in phospholipids, with 21\%-22\% free fatty acids) into plasma phospholipids [81]. A non-significant trend for higher incorporation of EPA and DHA from krill oil was reported [81]. Although the duration of the experiment was short (24 h), the investigators were careful to match the amount of EPA and DHA that was administered for the three preparations.

To investigate possible differential incorporation of EPA and DHA into membrane phospholipids, Judé et al. [79] fed dogs a diet containing a greater amount of DHA than EPA, for 8 weeks. As expected, the plasma concentration of DHA was greater than EPA. However, despite the intake of a DHA-rich diet, EPA was preferentially incorporated into erythrocyte and cardiac membrane phospholipids. The incorporation of EPA and DHA into phospholipids was also investigated in humans receiving dietary supplementation with LC $n$-3 PUFAs $[14,82,83]$. In these studies, EPA was also more efficiently incorporated into cholesteryl esters than DHA [14], and this was ascribed to a higher efficiency of lecithin-cholesterol acyltransferase (LCAT) activity for transfer of EPA from phosphatidylcholine to cholesteryl esters [82,84]. In contrast, DHA was preferentially incorporated into triglycerides [14], with DHA serving as a preferential substrate for diacylglycerol acyltransferase [52]. Interestingly, not all studies concur with this pattern of fatty acid metabolism. The supplementation of guinea-pigs with marine oils rich in EPA led to preferential incorporation of DHA into cardiac muscle total phospholipids [85]. Whilst species differences may be responsible for the different findings, this is unlikely to occur at the level of LCAT activity since LCAT activity in guinea-pig is intermediate between that reported in dog (lower activity than in guinea pig) and human (higher activity than in guinea pig) [86]. 
Both EPA and DHA decrease the liberation of arachidonic acid from phospholipids by inhibiting phospholipase $\mathrm{A}_{2}$ activity [87]. Arachidonic acid is a substrate for cyclooxygenase and lipoxygenase enzymes, and the competitive reduction in arachidonic acid by EPA and DHA inhibits the generation of the 2-series prostaglandins, and 4-series leukotrienes [88,89]. As described above, EPA is a better substrate than DHA for LCAT activity [82]. The displacement of arachidonic acid by EPA in phospholipids increases cyclooxygenase-2-mediated production of $\mathrm{PGE}_{3}$, and lipoxygenase-mediated production of $\mathrm{LTB}_{5}$, from EPA, with a concomitant reduction in levels of $\mathrm{PGE}_{2}$ and $\mathrm{LTB}_{4}$ [90-92]. The $\mathrm{PGE}_{2}$-to- $\mathrm{PGE}_{3}$ and $\mathrm{LTB}_{4}$-to-LTB $\mathrm{L}_{5}$ switching described by these investigators is likely to be of clinical importance in the in vivo modulation of disease since the EPA-derived products will tend to favour anti-inflammatory, anti-mitotic and anti-allergic activities [90-92].

Diacylglycerol is one of the lipid molecules into which EPA and DHA can be incorporated. This molecule has a key role in cell signaling, being a potent endogenous activator of conventional and novel subclasses of protein kinase C (PKC). Diets containing LC $n$-3 PUFAs lead to enrichment of these fatty acids in diacylglycerol [93], primarily in the $s n-2$ position [94]. Judé et al. [79] showed a preferential enrichment of cardiac membrane diacylglycerol with EPA compared to DHA in dogs that were fed a fish oil diet, while Madani et al. [56] showed preferential enrichment of Jurkat $\mathrm{T}$ cell diacylglycerol with DHA compared to EPA. In mice fed diets rich in EPA or DHA for 10 days, isolated splenic cells showed an apparent (data for $n=2$ experiments only) differential enrichment of diacylglcerol with 18:1-22:6(n-3) and 18:1-20:1(n-9) (DHA fed mice) or 18:0-18:2(n-6) (EPA fed mice) [95]. The findings show that diets containing high levels of EPA or DHA can lead to differential incorporation of fatty acids, including LC $n-3$ PUFAs, into diacylglycerol. The question arises as to whether this type of response might translate to differential effects on PKC signaling. This was examined in an in vitro study that compared the effects of diacylglycerol containing EPA or DHA in the $s n-2$ position, on PKC activity [96]. Both EPA and DHA-containing forms of diacylglycerol stimulated concentration-dependent $\mathrm{PKC} \alpha, \beta \mathrm{I}, \gamma, \delta$ and $\varepsilon$ activity, however differential responses were not observed [96]. The implication of this finding is that whilst differential incorporation of EPA and DHA into membrane phospholipids may contribute to differences in health benefits of the LC $n-3$ PUFAs, this is unlikely to occur at the level of diacylglycerol/ PKC signaling.

\subsection{LC n-3 PUFA Metabolites}

LC n-3 PUFAs undergo enzyme-independent auto-oxidation under cell culture conditions, increasing with time and with the level of unsaturation of the fatty acid (DHA > EPA; [97]. Since oxidation products can have different activity to the parent LC $n$-3 PUFA, differential stability of EPA and DHA may impact on the pharmacological effect of these fatty acids. Multiple enzyme systems also convert LC $n-3$ PUFAs to metabolites that have biological activity [98,99] (Figure 1). The family of cytochrome P450 (CYP450) enzymes convert EPA to primary metabolites epoxyeicosatetraenoic acid (17,18-EEQ) and hydroxyeicosapentaenoic acid (20-HEPE), and DHA to epoxydocosapentaenoic acid (19,20-EDP) and hydroxydocosahexaenoic acid (22-HDoHE) [100]. Treatment of human subjects with $1.86 \mathrm{~g}$ EPA and $1.5 \mathrm{~g}$ DHA per day for 4 weeks caused a 4.7- and 2.1-fold increases in plasma levels of 17,18-EEQ and 19,20-EDP, respectively [101]. EPA is also converted to $18 S$ - and $18 R$-resolvins E1 and $\mathrm{E} 2$ by aspirin-acetylated cyclooxygenase-2 (COX-2) and 5-lipoxygenase activity [102]. DHA is 
converted by aspirin-acetylated COX-2 to $17 R$-resolvins D1-D4 and $17 R$-protectin D1, and by 5- and 15-lipoxygenase to the $17 S$-series of these compounds [103-105].

Several studies have examined divergent activity EPA and DHA by studying the responses to their metabolites. Multiple isoforms of CYP450 contribute to the metabolism of EPA and DHA, and these can perform their catalytic function with different preference for the EPA and DHA substrates. For example, DHA is metabolized at a greater rate than EPA by CYP4F2, CYP4F3B, and CYP4F3A, while CYP4A11 and CYP2J2 preferentially metabolize EPA [99]. The response to the LC $n$-3 PUFAs will therefore be affected by expression levels of CYP450 isoforms in the tissues, as this will influence the degree to which EPA and DHA are metabolized. Importantly, the metabolites have different biological activities to each other, and to their parent LC n-3 PUFA (Figure 1). This point is exemplified by the markedly different potencies of EPA, DHA, and CYP450 metabolites of EPA and DHA for eliciting vasorelaxation. The potency of DHA for dilation of pre-constricted porcine coronary arterioles (apparent $\mathrm{pEC}_{50}, 5.1$ ) was $~ 336,000$-fold lower than for its metabolite, 19,20-EDP (pEC $\mathrm{p}_{50}$, 10.6) [106]. In contrast to the high potency of the DHA metabolite, the EPA metabolite 17,18-EEQ relaxed pre-constricted mouse mesenteric arteries with comparatively low potency $\left(\sim \mathrm{pEC}_{50}, 7.0\right)[107]$.

Figure 1. Metabolism of arachidonic acid, eicosapentaenoic acid and docosahexaenoic acid by cytochrome P450 (CYP450), cyclooxygenase-2 (COX-2), apirin-acetylated COX-2, and 15- and 5-lipoxygenases (LOX). Functional responses of metabolites are indicated [102,104-106,108-123]. 20-HETE, 20-hydroxyeicosatetraenoic acid; 11,12-EET, 11,12-epoxyeicosatrienoic acid; 20-HEPE, 20-hydroxyeicosapentaenoic acid; 17,18-EEQ, 17,18-epoxyeicosatetraenoic acid; 22-HDoHE, 22-hydroxydocosahexaenoic acid; 19,20-EDP, 19,20-epoxydocosapentaenoic acid; $\mathrm{TXA}_{2}$, thromboxane $\mathrm{A}_{2} ; \mathrm{TXA}$, thromboxane $\mathrm{A}_{3} ; \mathrm{PGI}_{2}$, prostacyclin; $\mathrm{PGI}_{3}$, prostaglandin $\mathrm{I}_{3}$; RvE1, resolvin $\mathrm{E} 1$; RvD1, resolvin D1; $\mathrm{LTB}_{4}$, leukotriene $\mathrm{B}_{4} ; \mathrm{LTB}_{5}$, leukotriene $\mathrm{B}_{5}$.

\begin{tabular}{|c|c|c|c|}
\hline Enzymes & Arachidonic acid & Eicosapentaenoic acid & Docosahexaenoic acid \\
\hline CYP 450 & $\begin{array}{l}\text { 20-HETE } \\
11,12 \mathrm{EET}^{\mathrm{b}}\end{array}$ & $\begin{array}{l}\text { 20-HEPE } \\
17,18 \mathrm{EEQ}^{\mathrm{i}}\end{array}$ & $\begin{array}{l}\text { 22-HDoHE } \\
19,20 \mathrm{EDP}^{\mathrm{p}}\end{array}$ \\
\hline $\mathrm{COX}-2$ & $\mathrm{TXA}_{2}{ }^{\mathrm{c}}, \mathrm{PGI}_{2}{ }^{\mathrm{d}}$ & $\mathrm{TXA}_{3}{ }^{\mathrm{j}}, \mathrm{PGI}_{3}{ }^{\mathrm{k}}$ & \\
\hline $\begin{array}{l}\text { Aspirin-acetylated } \\
\text { COX-2 }\end{array}$ & $\begin{array}{c}\text { 15-epi-Lipoxinse } \\
\text { (Also block TXA }{ }_{2} \& \\
\text { PG synthesis) }\end{array}$ & $\begin{array}{l}18 S \mathrm{RvE} 1^{1} \& 18 R-\mathrm{Rv} \mathrm{E} 1, \mathrm{E} 2^{\mathrm{m}} \\
\text { (also requires 5-LOX activity) }\end{array}$ & $\begin{array}{c}\text { 17R-Rv D1-D4q } \\
17 R \text {-Protectin D1 }\end{array}$ \\
\hline 15-LOX, 5-LOX & $\begin{array}{c}\operatorname{LTB}_{4}{ }^{{ }^{2}} \\
\text { Lipoxins }\end{array}$ & $\mathrm{LTB}_{5}{ }^{\mathrm{n}}$ & $\begin{array}{c}17 S \text {-Rv D1-D4s } \\
17 S \text {-Protectin } \mathrm{D}_{1}\end{array}$ \\
\hline & \multicolumn{3}{|c|}{$\begin{array}{l}\text { Vasoconstriction }^{\mathrm{a}} \\
\text { Potent and irreversible platelet aggregation }{ }^{\mathrm{c}} \\
\text { Neutrophil chemotaxis } \mathrm{f} \\
\text { Neutrophil activation and degranulation } \mathrm{g} \\
\text { Moderate and reversible platelet aggregation }{ }^{\mathrm{j}} \\
\text { Potent vasodilation } \mathrm{b}, \mathrm{d}, \mathrm{i}, \mathrm{k}, \mathrm{p} \\
\text { Inhibition of platelet aggregation } \mathrm{d}, \mathrm{k} \\
\text { Promote macrophage phagocytosis of neutrophils } \mathrm{e}, \mathrm{g}, 1 \\
\text { Decreased migration of neutrophils } \mathrm{e}, \mathrm{g}, 1, \mathrm{~m}, \mathrm{n}, \mathrm{q}, \mathrm{r}, \mathrm{s}, \mathrm{t} \\
\text { Bronchorelaxation } \mathrm{i}\end{array}$} \\
\hline
\end{tabular}


Polymorphisms in the gene encoding for the CYP450 isoforms may contribute to variation in metabolism of EPA and DHA between individuals. Several polymorphisms have been identified in the CYP1A1 gene, including a CYP1A1.2 variant (Ile462Val) that has allelic frequency up to $10 \%$ in Caucasians, and up to 33\% in Asians (see [124]). This variant form of CYP1A1 metabolizes EPA to 17,18-EEQ and 19-HEPE with a 2.1 and 5.2-fold higher efficiency than the wild type enzyme [124]. The ratio of efficiency of epoxygenation to hydroxylation is also different for the variant and wild-type enzymes [124]. Since the biological activity of the metabolites can differ (see above), polymorphisms may be expected to contribute to variability in differential effects of the LC $n-3$ PUFAs and their metabolites between individuals.

Differential responses have also been noted for the resolvins and lipoxins; families of autacoids with anti-inflammatory and pro-resolving activities. The resolvins mediate their effects, at least in part, through the activation of G protein coupled receptors; ALX/FPR2 and GPR32 for resolvin D1 and lipoxin A4 [71,108] and ChemR23 and BLT1 for resolvin E1 [108,125]. Some similarities exist in the functional response to the autacoids and their precursor molecules. For example, both resolvin D1 and DHA induced polarization of adipose tissue-infiltrating macrophages from an M1 to an M2 phenotype, as evidenced by the attenuation of M1 markers TNF- $\alpha$ and IL- 6 and induction of the M2 marker Arg1 [126]. However, despite these similarities, differences between the LC $n$-3 PUFAs and their metabolites have also been noted. Whereas resolvin D1 potently induced macrophage phagocytic activity, DHA had the opposite effect, and whereas $1 \mathrm{nM}$ resolvin D1 stimulated ROS production in peritoneal macrophages, DHA was without effect even when used at a 10,000-fold higher concentration [126]. It is thus possible that some of the differential responses reported for EPA and DHA might be attributable to the extent to which they are metabolized by the different enzyme systems to their endogenous autacoid metabolites. In addition to the differences observed between the metabolites and their parent LC $n$-3 PUFA, differences have also been reported for anti-inflammatory and pro-resolving activity between the various metabolites. For example, $17 R$-resolvin $\mathrm{D} 1$, formed by aspirin-acetylated COX-2, was more potent than lipoxygenase-generated $17 S$-resolvin D1 at inhibiting leukocyte infiltration in a mouse-model of peritonitis [105]. Differential kinetics for onset of anti-inflammatory and pro-resolving activity for the metabolites of arachidonic acid, EPA and DHA may contribute to some of the differential responses reported for these mediators. A stable analogue of 15-epi-lipoxin A4 inhibited pro-inflammatory cytokine production in a mouse-model of peritonitis, $4 \mathrm{~h}$ after administration [127]. At this time-point, resolvin E1 was without effect, however when assessed $12 \mathrm{~h}$ post-administration, it inhibited pro-inflammatory cytokine production with magnitude equal to, or greater than that observed for the lipoxin [127]. Few studies have examined the biological activities of the CYP450 metabolites, and further research into this area is warranted.

\section{Conclusions}

Long chain omega-3 polyunsaturated fatty acids (LC $n$-3 PUFAs), eicosapentaenoic acid (EPA) and docosahexaenoic acid (DHA), have been recommended for management of patients with wide-ranging chronic diseases, including coronary heart disease, rheumatoid arthritis, dementia, and depression. Although there is much evidence supporting uniformity of response to the individual LC $n-3$ PUFAs, there are also a plethora of studies that have shown qualitative and quantitative differences in response 
to EPA and DHA. In this review, we have explored some of the reasons for these differences. We propose that there are multiple factors that contribute to the differential effects of EPA and DHA, including differences in direct and indirect activation of transcription factors, impact of length, degree of saturation and stability of the fatty acid on efficacy, and differential efficiency for incorporation of the fatty acids into phospholipids. In addition, potency of the metabolites of EPA and DHA are often markedly different to the parent LC n-3 PUFA, and divergence in efficiency of enzymes to metabolize EPA and DHA can contribute to observed diversity in cellular response. We suggest that with improved understanding of the similarities and differences for EPA and DHA, an opportunity exists to customize recommendations for intake of EPA or DHA that can be tailored to the patient's condition.

\section{References}

1. Fortin, P.R.; Lew, R.A.; Liang, M.H.; Wright, E.A.; Beckett, L.A.; Chalmers, T.C.; Sperling, R.I. Validation of a meta-analysis: the effects of fish oil in rheumatoid arthritis. J. Clin. Epidemiol. 1995, 48, 1379-1390.

2. Geleijnse, J.M.; Giltay, E.J.; Grobbee, D.E.; Donders, A.R.T.; Kok, F.J. Blood pressure response to fish oil supplementation: Metaregression analysis of randomized trials. J. Hypertens. 2002, 20, 1493-1499.

3. Morris, M.C.; Evans, D.A.; Bienias, J.L.; Tangney, C.C.; Bennett, D.A.; Wilson, R.S.; Aggarwal, N.; Schneider, J. Consumption of fish and n-3 fatty acids and risk of incident Alzheimer Disease. Arch. Neurol. 2003, 60, 940-946.

4. Martins, J.G. EPA but not DHA appears to be responsible for the efficacy of omega-3 long chain polyunsaturated fatty acid supplementation in depression: Evidence from a meta-analysis of randomized controlled trials. J. Am. Coll. Nutr. 2009, 28, 525-542.

5. Kwak, S.M.; Myung, S.-K.; Lee, Y.J.; Seo, H.G. Efficacy of omega-3 fatty acid supplements (eicosapentaenoic acid and docosahexaenoic acid) in the secondary prevention of cardiovascular disease. A meta-analysis of randomized, double-blind, placebo-controlled trials. Arch. Intern. Med. 2012, 172, 686-694.

6. Rizos, E.C.; Nitzani, E.E.; Bika, E.; Kostapanos, M.S.; Elisaf, M.S. Association between omega-3 fatty acid supplementation and risk of major cardiovascular disease events: A systematic review and meta-analysis. JAMA 2012, 308, 1024-1033.

7. Burr, M.L.; Fehily, A.M.; Gilbert, J.F.; Rogers, S.; Holliday, R.M.; Sweetnam, P.M.; Elwood, P.C.; Deadman, N.M. Effects of changes in fat, and fibre intakes on death and myocardial reinfarction: Diet and reinfarction trial (DART). Lancet 1989, 2, 757-761.

8. GISSI-Prevenzione Investigators. Dietary supplemenatation with $n-3$ polyunsaturated fatty acids and vitamin E after myocardial infarction: Results of the GISSI-Prevenzione trial. Lancet 1999, 354, 447-455.

9. Kromhout, D. Omega-3 fatty acids and coronary heart disease. The final verdict? Curr. Opin. Lipidol. 2012, 23, doi:10.1097/MOL.0b013e328359515f.

10. Laufs, U.; Schirmer, S.H. Margarines supplemented with low dose $n-3$ fatty acids are not effective in secondary prevention. Eur. Heart J. 2012, 33, 1555-1557. 
11. O’Sullivan, T.A.; Ambrosini, G.; Beilin, L.J.; Mori, T.A.; Oddy, W.H. Dietary intake and food sources of fatty acids in Australian adolescents. Nutrition 2011, 27, 153-159.

12. Gibson, R.A.; Neumann, M.A.; Lien, E.L.; Boyd, K.A.; Tu, W.C. Docosahexaenoic acid synthesis from alpha-linolenic acid is inhibited by diets high in polyunsaturated fatty acids. Prostaglandins Leukot. Essent. Fatty Acids 2012, doi.org/10.1016/j.plefa.2012.04.003.

13. Burdge, G.C.; Finnegan, Y.E.; Minihane, A.M.; Williams, C.M.; Wootton, S.A. Effect of altered dietary $n-3$ fatty acid intake upon plasma lipid fatty acid composition, conversion of [13C] $\alpha$-linolenic acid to longer-chain fatty acids and partitioning towards $\beta$-oxidation in older men. Br. J. Nutr. 2003, 90, 311-321.

14. Singer, P.; Berger, I.; Wirth, M.; Gödicke, W.; Jaeger, W.; Voigt, S. Slow desaturation and elongation of linoleic and $\alpha$-linolenic acids as a rationale of eicosapentaenoic acid-rich diet to lower blood pressure and serum lipids in normal, hypertensive and hyperlipidemic subjects. Prostaglandins Leukot. Med. 1986, 24, 173-193.

15. Block, R.C.; Harris, W.S.; Pottala, J.V. Determinants of blood cell omega-3 fatty acid content. Open Biomark. J. 2008, 1, 1-6.

16. Astorg, P.; Arnault, N.; Czernichow, S.; Noisette, N.; Galan, P.; Hercberg, S. Dietary intakes and food sources of $n$ - and $n$-3 PUFA in French adult men and women. Lipids 2004, 39, 527-535.

17. Howe, P.; Meyer, B.; Record, S.; Baghurst, K. Dietary intake of long-chain $\omega-3$ polyunsaturated fatty acids: Contribution of meat sources. Nutrition 2006, 22, 47-53.

18. Yamagishi, K.; Iso, H.; Date, C.; Fukui, M.; Wakai, K.; Kikuchi, S.; Inaba, Y.; Tanabe, N.; Tamakoshi, A. Fish, $\omega-3$ polyunsaturated fatty acids, and mortality from cardiovascular diseases in a nationwide community-based cohort of Japanese men and women. J. Am. Coll. Cardiol. 2008, 52, 988-996.

19. Scientific Advisory Committee on Nutrition. Advice on Fish Consumption: Benefits \& Risks. Available online: http://www.sacn.gov.uk/pdfs/fics_sacn_advice_fish.pdf (accessed on 5 September 2012).

20. French Agency for Food, Environmental and Occupational Health \& Safety. Opinion of the French Food Safety Agency Regarding the Benefits/Risks of Fish Consumption. Available online: http://www.anses.fr/Documents/NUT2008sa0123EN.pdf (accessed on 5 September 2012).

21. Health Council of the Netherlands. Guidelines for a Healthy Diet. Available online: http://www.gezondheidsraad.nl/en/publications/guidelines-healthy-diet-2006-0 (accessed on 5 September 2012).

22. Heart Foundation of Australia. Position Statement, 2008: Fish, Fish Oils, n-3 Polyunsaturated Fatty Acids and Cardiovascular Health. Available online: http://www.heartfoundation.org.au/ SiteCollection Documents/Fish-position-statement.pdf (accessed on 5 September 2012).

23. Freeman, M.P.; Hibbeln, J.R.; Wisner, K.L.; Davis, J.M.; Mischoulon, D.; Peet, M.; Keck, P.E.; Marangell, L.B.; Richardson, A.J.; Lake, J.; Stoll, A.L. Omega-3 fatty acids: Evidence basis for treatment and future research in psychiatry. J. Clin. Psychiatry 2006, 67, 1954-1967.

24. McNamara, R.K. Evaluation of docosahexaenoic acid deficiency as a preventable risk factor for recurrent affective disorders: Current status, future direction, and dietary recommendations. Prostaglandins Leukot. Essent. Fatty Acids 2009, 81, 223-231. 
25. Sumich, A.; Matsudaira, T.; Gow, R.V.; Ibrahimovic, A.; Ghebremeskel, K.; Crawford, M.; Taylor, E. Resting state electroencephalographic correlates with red cell long-chain fatty acids, memory performance and age in adolescent boys with attention deficit disorder. Neuropharmacology 2009, 57, 708-714.

26. Mori, T.A.; Bao, D.Q.; Burke, V.; Puddey, I.B.; Beilin, L.J. Docosahexaenoic acid but not eicosapentaenoic acid lowers ambulatory blood pressure and heart rate in humans. Hypertension 1999, 34, 253-260.

27. Rousseau-Ralliard, D.; Moreau, D.; Guilland, J.-C.; Raederstorff, D.; Grynberg, A. Docosahexaenoic acid, but not eicosapentaenoic acid, lowers ambulatory blood pressure and shortens interval QT in spontaneously hypertensive rats in vivo. Prostaglandins Leukot. Essent. Fatty Acids 2009, 80, 269-277.

28. Park, Y.; Harris, W. EPA, but not DHA, decreases mean platelet volume in normal subjects. Lipids 2002, 37, 941-946.

29. Phang, M.; Garg, M.L.; Sinclair, A.J. Inhibition of platelet aggregation by omega-3 polyunsaturated fatty acids is gender specific-Redefining platelet response to fish oils. Prostaglandins Leukot. Essent. Fatty Acids 2009, 81, 35-40.

30. Hamilton, K.; Brooks, P.; Holmes, M.; Cunningham, J.; Russell, F.D. Evaluation of the composition of omega-3 fatty acids in dietary oil supplements. Nutr. Diet. 2010, 67, 182-189.

31. Phang, M.; Sinclair, A.J.; Lincz, L.F.; Garg, M.L. Gender-specific inhibition of platelet aggregation following omega-3 fatty acid supplementation. Nutr. Metab. Cardiovasc. Dis. 2012, $22,109-114$.

32. Salunkhe, D.; Tiwari, N.; Walujkar, S.; Bhadekar, R. Halomonas sp. nov., an EPA-producing mesophilic marine isolate from the Indian Ocean. Pol. J. Microbiol. 2011, 60, 73-78.

33. Soltan, S.S.A.M.; Gibson, R.A. Levels of omega 3 fatty acids in Australian seafood. Asia Pac. J. Clin. Nutr. 2008, 17, 385-390.

34. Kris-Etherton, P.M.; Harris, W.S.; Appel, L.J. Omega-3 fatty acids and cardiovascular disease. New recommendations from the American Heart Association. Arterioscler. Thromb. Vasc. Biol. 2003, 23, 151-152.

35. World Health Organisation. Population Nutrient Intake Goals for Preventing Diet-Related Chronic Diseases. Available online: http://www.who.int/nutrition/topics/5_population_nutrient/ en/index13.html (accessed on 5 September 2012).

36. Nutrient Reference Values for Australia and New Zealand. Available online: http://www.nrv.gov.au/resources/_files/n35-fat.pdf (accessed on 5 September 2012).

37. Cancer Council of Australia. Position Statement, 2009: Omega-3 Fatty Acids, Fish and Cancer Prevention. Available online: http://www.cancercouncil.com.au/wp-content/uploads/2010/09/ Fish-Omega3-Fatty-Acids-and-Cancer-Position-Statement.pdf (accessed on 5 September 2012).

38. International Society for the Study of Fatty Acids and Lipids. Intake of PUFA in Health Adults. Available online: http://www.issfal.org/statements/pufa-recommendations/statement-3 (accessed on 5 September 2012). 
39. Yusufi, A.N.K.; Cheng, J.; Thompson, M.A.; Walker, H.J.; Gray, C.E.; Warner, G.M.; Grande, J.P. Differential effects of low-dose docosahexaenoic acid and eicosapentaenoic acid on the regulation of mitogenic signalling pathways in mesangial cells. J. Lab. Clin. Med. 2003, 141, 318-330.

40. Owen, A.J.; Peter-Przyborowska, B.A.; Hoy, A.J.; McLennan, P.L. Dietary fish oil dose- and time-response effects on cardiac phospholipid fatty acid composition. Lipids 2004, 39, 955-961.

41. Verlengia, R.; Gorjão, R.; Kanunfre, C.C.; Bordin, S.; de Lima, T.M.; Martins, E.F.; Curi, R. Comparative effects of eicosapentaenoic acid and docosahexaenoic acid on proliferation, cytokine production, and pleiotropic gene expression in Jurkat cells. J. Nutr. Biochem. 2004, 15, 657-665.

42. Grimsgaard, S.; Bønaa, K.H.; Hansen, J.-B.; Myhre, E.S.P. Effects of highly purified eicosapentaenoic acid and docosahexaenoic acid on hemodynamics in humans. Am. J. Clin. Nutr. 1998, 68, 52-59.

43. Weldon, S.M.; Mullen, A.C.; Loscher, C.E.; Hurley, L.A.; Roche, H.M. Docosahexaenoic acid induces an anti-inflammatory profile in lipopolysaccharide-stimulated human THP-1 macrophages more effectively than eicosapentaenoic acid. J. Nutr. Biochem. 2007, 18, 250-258.

44. Caputo, M.; Zirpoli, H.; Torino, G.; Tecce, M.F. Selective regulation of UGT1A1 and SREBP-1c mRNA expression by docosahexaenoic, eicosapentaenoic, and arachidonic acids. J. Cell. Physiol. 2010, 226, 187-193.

45. Hutchins, H.L.; Li, Y.; Hannon, K.; Watkins, B.A. Eicosapentaenoic acid decreases expression of anandamide synthesis enzyme and cannabinoid receptor 2 in osteoblast-like cells. J. Nutr. Biochem. 2011, 22, 195-200.

46. Oster, R.T.; Tishinsky, J.M.; Yuan, Z.; Robinson, L.E. Docosahexaenoic acid increases cellular adiponectin mRNA and secreted adiponectin protein, as well as PPAR $\gamma$ mRNA, in 3T3-L1 adipocytes. Appl. Physiol. Nutr. Metab. 2010, 35, 783-789.

47. Wang, D.; Hirase, T.; Nitto, T.; Soma, M.; Node, K. Eicosapentaenoic acid increases cytochrome P-450 2J2 gene expression and epoxyeicosatrienoic acid production via peroxisome proliferator-activated receptor $\gamma$ in endothelial cells. J. Cardiol. 2009, 54, 368-374.

48. Mori, T.A.; Burke, V.; Puddey, I.B.; Watts, G.F.; O’Neal, D.N.; Best, J.D.; Beilin, L.J. Purified eicosapentaenoic and docosahexaenoic acids have differential effects on serum lipids and lipoproteins, LDL particle size, glucose, and insulin in mildly hyperlipidemic men. Am. J. Clin. Nutr. 2000, 71, 1085-1094.

49. Grimsgaard, S.; Bønaa, K.H.; Hansen, J.-B.; Nordøy, A. Highly purified eicosapentaenoic acid and docosahexaenoic acid in humans have similar triacylglycerol-lowering effects but divergent effects on serum fatty acids. Am. J. Clin. Nutr. 1997, 66, 649-659.

50. Egert, S.; Kannenberg, F.; Somoza, V.; Erbersdobler, H.F.; Wahrburg, U. Dietary $\alpha$-linolenic acid, EPA, and DHA have differential effects on LDL fatty acid composition but similar effects on serum lipid profiles in normolipidemic humans. J. Nutr. 2009, 139, 861-868.

51. Woodman, R.J.; Mori, T.A.; Burke, V.; Puddey, I.B.; Watts, G.F.; Best, J.D.; Beilin, L.J. Docosahexaenoic acid but not eicosapentaenoic acid increases LDL particle size in treated hypertensive type 2 diabetic patients. Diabetes Care 2003, 26, 253. 
52. Madsen, L.; Rustan, A.C.; Vaagenes, H.; Berge, K.; Dyrøy, E.; Berge, R.K. Eicosapentaenoic and docosahexaenoic acid affect mitochondrial and peroxisomal fatty acid oxidation in relation to substrate preference. Lipids 1999, 34, 951-963.

53. Leonardi, F.; Attorri, L.; di Benedetto, R.; di Biase, A.; Sanchez, M.; Nardini, M.; Salvati, S. Effect of arachidonic, eicosapentaenoic and docosahexaenoic acids on the oxidative status of C6 glioma cells. Free Radic. Res. 2005, 39, 865-874.

54. Tonutti, L.; Manzi, L.; Tacconi, M.T.; Bazzoni, G. Eicosapentaenoic acid inhibits endothelial cells migration in vitro. J. Angiogenesis Res. 2010, 2, 12.

55. Brown, E.R.; Subbaiah, P.V. Differential effects of eicosapentaenoic acid and docosahexaenoic acid on human skin fibroblasts. Lipids 1994, 29, 825-829.

56. Madani, S.; Hichami, A.; Charkaoui-Malki, M.; Khan, N.A. Diacylglycerols containing omega 3 and omega 6 fatty acids bind to RasGRP and modulate MAP kinase activation. J. Biol. Chem. 2004, 279, 1176-1183.

57. Woodman, R.J.; Mori, T.A.; Burke, V.; Puddey, I.B.; Barden, A.; Watts, G.F.; Beilin, L.J. Effects of purified eicosapentaenoic acid and docosahexaenoic acid on platelet, fibrinolytic and vascular function in hypertensive type 2 diabetic patients. Atherosclerosis 2003, 166, 85-93.

58. Barden, A.; Mas, E.; Henry, P.; Durand, T.; Galano, J.M.; Roberts, L.J.; Croft, K.D.; Mori, T.A. The effects of oxidation products of arachidonic acid and $\mathrm{n} 3$ fatty acids on vascular and platelet function. Free Radic. Res. 2011, 45, 469-476.

59. Pisani, L.F.; Lecchi, C.; Invernizzi, G.; Sartorelli, P.; Savoini, G.; Ceciliani, F. In vitro modulatory effect of $\omega-3$ polyunsaturated fatty acid (EPA and DHA) on phagocytosis and ROS production of goat neutrophils. Vet. Immunol. Immunopathol. 2009, 131, 79-85.

60. Komatsu, W.; Ishihara, K.; Murata, M.; Saito, H.; Shinohara, K. Docosahexaenoic acid suppresses nitric oxide production and inducible nitric oxide synthase expression in interferon- $\gamma$ plus lipopolysaccharide-stimulated murine macrophages by inhibiting the oxidative stress. Free Radic. Biol. Med. 2003, 34, 1006-1016.

61. Khairallah, R.J.; Sparagna, G.C.; Khanna, N.; O’Shea, K.M.; Hecker, P.A.; Kristian, T.; Fiskum, G.; des Rosiers, C.; Polster, B.M.; Stanley, W.C. Dietary supplementation with docosahexaenoic acid, but not eicosapentaenoic acid, dramatically alters cardiac mitochondrial phospholipid fatty acid composition and prevents permeability transition. Biochim. Biophys. Acta 2010, 1797, $1555-1562$.

62. McLennan, P.; Howe, P.; Abeywardena, M.; Muggli, R.; Raederstorff, D.; Mano, M.; Rayner, T.; Head, R. The cardiovascular protective role of docosahexaenoic acid. Eur. J. Pharmacol. 1996, 300, 83-89.

63. Mori, T.A.; Watts, G.F.; Burke, V.; Hilme, E.; Puddey, I.B.; Beilin, L.J. Differential effects of eicosapentaenoic acid and docosahexaenoic acid on vascular reactivity of the forearm microcirculation in hyperlipidemic, overweight men. Circulation 2000, 102, 1264-1269.

64. Liu, R.-Z.; Graham, K.; Clubrecht, D.D.; Lai, R.; Mackey, J.; Godbout, R. A fatty acid-binding protein $7 / \mathrm{RXR} \beta$ pathway enhances survival and proliferation in triple-negative breast cancer. J. Pathol. 2012, 228, 310-321. 
65. Balendiran, G.K.; Schnütgen, F.; Scapin, G.; Börchers, T.; Xhong, N.; Lim, K.; Godbout, R.; Spener, F.; Sacchettini, J.C. Crystal structure and thermodynamic analysis of human brain fatty acid-binding protein. J. Biol. Chem. 2000, 275, 27045-27054.

66. Edwards, I.J.; O'Flaherty, J.T. Omega-3 fatty acids and PPAR $\gamma$ in cancer. PPAR Res. 2008, 2008, 358052.

67. Comba, A.; Lin, Y.-H.; Eynard, A.R.; Valentich, M.A.; Fernandez-Zapico, M.E.; Pasqualini, M.E. Basic aspects of tumor cell fatty acid-regulated signalling and transcription factors. Cancer Metastasis Rev. 2011, 30, 325-342.

68. Li, H.; Ruan, X.Z.; Powis, S.H.; Fernando, R.; Mon, W.Y.; Wheeler, D.C.; Moorhead, J.F.; Varghese, Z. EPA and DHA reduce LPS-induced inflammation responses in HK-2 cells: Evidence for a PPAR- $\gamma$-dependent mechanism. Kidney Int. 2005, 67, 867-874.

69. Yamamoto, K.; Itoh, T.; Abe, D.; Shimizu, M.; Kanda, T.; Koyama, T.; Nishikawa, M.; Tamai, T.; Ooizumi, H.; Yamada, S. Identification of putative metabolites of docosahexaenoic acid as potent PPAR $\gamma$ agonists and antidiabetic agents. Bioorg. Med. Chem. Lett. 2005, 15, 517-522.

70. Itoh, T.; Yamamoto, K. Peroxisome proliferator activated receptor $\gamma$ and oxidized docosahexaenoic acids as new class of ligand. Naunyn Schmiedeberg Arch. Pharmacol. 2008, 377, 541-547.

71. Krishnamoorthy, S.; Recchiuti, A.; Chiang, N.; Yacoubian, S.; Lee, C.-H.; Yang, R.; Petasis, N.; Serhan, C.N. Resolvin D1 binds human phagocytes with evidence for proresolving receptors. Proc. Natl. Acad. Sci. USA 2010, 107, 1660-1665.

72. Zhao, Y.; Joshi-Barve, S.; Barve, S.; Chen, L.H. Eicosapentaenoic acid prevents LPS-induced TNF- $\alpha$ expression by preventing NF- $\mathrm{BB}$ activation. J. Am. Coll. Nutr. 2004, 23, 71-78.

73. Wong, S.W.; Kwon, M.-J.; Choi, A.M.K.; Kim, H.-P.; Nakahira, K.; Hwang, D.H. Fatty acids modulate Toll-like receptor 4 activation through regulation of receptor dimerization and recruitment into lipid rafts in a reactive oxygen species-dependent manner. J. Biol. Chem. 2009, 284, 27384-27392.

74. Hirasawa, A.; Tsumaya, K.; Awaji, T.; Katsuma, S.; Adachi, T.; Yamada, M.; Sugimoto, Y.; Miyazaki, S.; Tsujimoto, G. Free fatty acids regulate gut incretin glucagon-like peptide-1 secretion through GPR120. Nat. Med. 2005, 11, 90-94.

75. Miyauchi, S.; Hirasawa, A.; Iga, T.; Liu, N.; Itsubo, C.; Sadakane, K.; Hara, T.; Tsujimoto, G. Distribution and regulation of protein expression of the free fatty acid receptor GPR120. Naunyn Schmiedeberg Arch. Pharmacol. 2009, 379, 427-434.

76. Oh, D.Y.; Talukdar, S.; Bae, E.J.; Imamura, T.; Morinaga, H.; Fan, W.Q.; Li, P.; Lu, W.J.; Watkins, S.M.; Olefsky, J.M. GPR120 is an omega-3 fatty acid receptor mediating potent anti-inflammatory and insulin-sensitizing effects. Cell 2010, 142, 687-698.

77. Morishita, M.; Tanak, T.; Shida, T.; Takayama, K. Usefulness of colon targeted DHA and EPA as novel diabetes medications that promote intrinsic GLP-1 secretion. J. Control. Release 2008, 132, 99-104.

78. Burns, R.N.; Moniri, N.H. Agonism with the omega-3 fatty acids $\alpha$-linolenic acid and docosahexaenoic acid mediates phosphorylation of both the short and long isoforms of the human GPR120 receptor. Biochem. Biophys. Res. Commun. 2010, 396, 1030-1035. 
79. Judé, S.; Martel, E.; Vincent, F.; Besson, P.; Couet, C.; Ogilvie, G.K.; Pinault, M.; de Chalendar, C.; Bougnoux, P.; Richard, S.; et al. Dietary long-chain $n-3$ fatty acids modify blood and cardiac phospholipids and reduce protein kinase-C- $\delta$ and protein kinase-C- $\varepsilon$ translocation. Br. J. Nutr. 2007, 98, 1143-1151.

80. O’Shea, K.M.; Khairallah, R.J.; Sparagna, G.C.; Xu, W.; Hecker, P.A.; Robillard-Frayne, I.; des Rosiers, C.; Kristian, T.; Murphy, R.C.; Fiskum, G.; et al. Dietary $\omega-3$ fatty acids alter cardiac mitochondrial phospholipid composition and delay $\mathrm{Ca}^{2+}$-induced permeability transition. J. Mol. Cell. Cardiol. 2009, 47, 819-827.

81. Schuchardt, J.P.; Schneider, I.; Meyer, H.; Neubronner, J.; von Schacky, C.; Hahn, A. Incorporation of EPA and DHA into plasma phospholipids in response to different omega-3 fatty acid formulations - A comparative bioavailability study of fish oil vs. krill oil. Lipids Health Dis. 2011, 10, 145.

82. Holub, B.J.; Bakker, D.J.; Skeaff, C.M. Alterations in molecular species of cholesterol esters formed via plasma lecithin-cholesterol acyltransferase in human subjects consuming fish oil. Atherosclerosis 1987, 66, 11-18.

83. Subbaiah, P.V.; Kaufman, D.; Bagdade, J.D. Incorporation of dietary $n-3$ fatty acids into molecular species of phosphatidyl choline and cholesteryl ester in normal human plasma. Am. $J$. Clin. Nutr. 1993, 58, 360-380.

84. Parks, J.S.; Thuren, T.Y.; Schmitt, J.D. Inhibition of lecithin: Cholesterol acyltransferase activity by synthetic phosphatidylcholine species containing eicosapentaenoic acid or docosahexaenoic acid in the sn-2 position. J. Lipid Res. 1992, 33, 879-887.

85. Murphy, M.G.; Wright, V.; Ackman, R.G.; Horackova, M. Diets enriched in menhaden fish oil, seal oil, or shark liver oil have distinct effects on the lipid and fatty-acid composition of guinea pig heart. Mol. Cell. Biochem. 1997, 177, 257-269.

86. Ha, Y.C.; Barter, P.J. Differences in plasma cholesteryl ester transfer activity in sixteen vertebrate species. Comp. Biochem. Physiol. 1982, 71B, 265-269.

87. Shikano, M.; Masuzawa, Y.; Yazawa, K.; Takayama, K.; Kudo, I.; Inoue, K. Complete discrimination of docosahexaenoate from arachidonate by $85 \mathrm{kDa}$ cytosolic phospholipase A2 during the hydrolysis of diacyl- and alkenylacylglycerophosphoethanolamine. Biochim. Biophys. Acta 1994, 1212, 211-216.

88. Chaudry, A.A.; Wahle, K.W.; McClinton, S.; Moffat, L.E. Arachidonic acid metabolism in benign and malignant prostatic tissue in vitro: Effects of fatty acids and cyclooxygenase inhibitors. Int. J. Cancer 1994, 57, 176-180.

89. Raederstorff, D.; Pantze, M.; Bachmann, H.; Moser, U. Anti-inflammatory properties of docosahexaenoic and eicosapentaenoic acids in phorbol-ester-induced mouse ear inflammation. Int. Arch. Allergy Immunol. 1996, 111, 284-290.

90. Payan, D.G.; Wong, M.Y.; Chernov-Rogan, T.; Valone, F.H.; Pickett, W.C.; Blake, V.A.; Gold, W.M.; Goetzl, E.J. Alterations in human leukocyte function induced by ingestion of eicosapentaenoic acid. J. Clin. Immunol. 1986, 6, 402-410.

91. Hung, P.; Kaku, S.; Yunoki, S.; Ohkura, K.; Gu, J.-Y.; Ikeda, I.; Sugano, M.; Yazawa, K.; Yamada, K. Dietary effect of EPA-rich and DHA-rich fish oils on the immune function of Sprague-Dawley rats. Biosci. Biotechnol. Bochem. 1999, 63, 135-140. 
92. Hawcroft, G.; Loadman, P.M.; Belluzzi, A.; Hull, M.A. Effect of eicosapentaenoic acid on E-type prostaglandin synthesis and EP4 receptor signalling in human colorectal cancer cells. Neoplasia 2010, 12, 618-627.

93. Pehowich, D.J. Dietary $n-3$ fatty acids alter angiotensin-induced contraction and 1,2-diacylglycerol fatty acid composition in thoracic aortas from diabetic rats. Prostaglandins Leukot. Essent. Fatty Acids 1998, 58, 301-309.

94. Hichami, A.; Morin, C.; Rousseau, E.; Khan, N.A. Diacylglycerol-containing docosahexaenoic acid in acyl chain modulates airway smooth muscle tone. Am. J. Respir. Cell Mol. Biol. 2005, 33, 378-386.

95. Fowler, K.H.; McMurray, D.N.; Fan, Y.-Y.; Aukema, H.M.; Chapkin, R.S. Purified dietary n-3 polyunsaturated fatty acids alter diacylglycerol mass and molecular species composition in concanavalin A-stimulated murine splenocytes. Biochim. Biophys. Acta 1993, 1210, 89-96.

96. Madani, S.; Hichami, A.; Legrand, A.; Belleville, J.; Khan, N.A. Implication of acyl chain of diacylglycerols in activation of different isoforms of protein kinase C. FASEB J. 2001, 15, 2595-2601.

97. Maddipati, K.R.; Zhou, S.-L. Stability and analysis of eicosanoids and docosanoids in tissue culture media. Prostaglandins Other Lipid Mediat. 2011, 94, 59-72.

98. Harmon, S.D.; Fang, X.; Kaduce, T.L.; Hu, S.; Gopal, V.R.; Falck, J.R.; Spector, A.A. Oxygenation of $\omega-3$ fatty acids by human cytochrome P450 4F3B: Effect on 20-hydroxyeicosatetraenoic acid production. Prostaglandins Leukot. Essent. Fatty Acids 2006, 75, 169-177.

99. Arnold, C.; Markovic, M.; Blossey, K.; Wallukat, G.; Fischer, R.; Dechend, R.; Konkel, A.; von Schacky, C.; Luft, F.C.; Muller, D.N.; et al. Arachidonic acid-metabolizing cytochrome P450 enzymes are targets of $\omega$-3 fatty acids. J. Biol. Chem. 2010, 285, 32720-32733.

100. Konkel, A.; Schunck, W.-H. Role of cytochrome P450 enzymes in the bioactivation of polyunsaturated fatty acids. Biochim. Biophys. Acta 2011, 1814, 210-222.

101. Shearer, G.C.; Harris, W.S.; Pedersen, T.L.; Newman, J.W. Detection of omega-3 oxylipins in human plasma and response to treatment with omega-3 acid ethyl esters. J. Lipid Res. 2010, 51, 2074-2081.

102. Oh, S.F.; Pillai, P.S.; Recchiuti, A.; Yang, R.; Serhan, C.N. Pro-resolving actions and stereoselective biosynthesis of $18 \mathrm{~S}$ E-series resolvins in human leukocytes and murine inflammation. J. Clin. Invest. 2011, 121, 569-581.

103. Serhan, C.N.; Hong, S.; Gronert, K.; Colgan, S.P.; Devchand, P.R.; Mirick, G.; Moussignac, R.-L. A family of bioactive products of omega-3 fatty acid transformation circuits initiated by aspirin treatment that counter proinflammation signals. J. Exp. Med. 2002, 196, 1025-1037.

104. Hong, S.; Gronert, K.; Devchand, P.R.; Moussignac, R.-L.; Serhan, C.N. Novel Docosatrienes and $17 S$-resolvins generated from docosahexaenoic acid in murine brain, human blood, and glial cells. J. Biol. Chem. 2003, 278, 14677-14687.

105. Sun, Y.-P.; Oh, S.F.; Uddin, J.; Yang, R.; Gotlinger, K.; Campbell, E.; Colgan, S.P.; Petasis, N.A.; Serhan, C.N. Resolvin D1 and its aspirin-triggered $17 R$ epimer: Stereochemical assignments, anti-inflammatory properties, and enzymatic inactivation. J. Biol. Chem. 2007, 282, 9323-9334. 
106. Ye, D.; Zhang, D.; Oltman, C.; Dellsperger, K.; Lee, H.-C.; Vanrollins, M. Cytochrome P-450 epoxygenase metabolites of docosahexaenoate potently dilate coronary arterioles by activating large-conductance calcium-activated potassium channels. J. Pharmacol. Exp. Ther. 2002, 303, 768-776.

107. Hercule, H.C.; Salanova, B.; Essin, K.; Honeck, H.; Falck, J.R.; Sausbier, M.; Ruth, P.; Schunck, W.-H.; Luft, F.C.; Gollasch, M. The vasodilator 17,18-epoxyeicosatetraenoic acid targets the pore-forming BK $\alpha$ channel subunit in rodents. Exp. Physiol. 2007, 92, 1067-1076.

108. Fredman, G.; Serhan, C.N. Specialized proresolving mediator targets for RvE1 and RvD1 in peripheral blood and mechanisms of resolution. Biochem. J. 2011, 437, $185-197$.

109. Wang, J.-S.; Singh, H.; Zhang, F.; Ishizuka, T.; Deng, H.; Kemp, R.; Wolin, M.S.; Hintze, T.H.; Abraham, N.G.; Nasjletti, A.; Laniado-Schwartzman, M. Endothelial dysfunction and hypertension in rats transduced with CYP4A2 adenovirus. Circ. Res. 2006, 98, 962-969.

110. Cheng, J.; Ou, J.-S.; Singh, H.; Falxk, J.R.; Narsimhaswany, D.; Pritchard, K.A.; Laniado-Schwartzman, M. 20-hydroxyeicosatetraenoic acid causes endothelial dysfunction via eNOS uncoupling. Am. J. Physiol. Heart Circ. Physiol. 2008, 294, H1018-H1026.

111. Campbell, W.B.; Gebremedhin, D.; Pratt, P.F.; Harder, D.R. Identification of epoxyeicosatrienoic acids as endothelium-derived hyperpolarizing factors. Circ. Res. 1996, 78, 415-423.

112. Fisslthaler, B.; Popp, R.; Kiss, L.; Potente, M.; Harder, D.R.; Fleming, I.; Busse, R. Cytochrome P450 2C is an EDHF synthase in coronary arteries. Nature 1999, 401, 493-497.

113. Wada, M.; DeLong, C.J.; Hong, Y.H.; Rieke, C.J.; Song, I.; Sidhu, R.S.; Yuan, C.; Warnock, M.; Schmaier, A.H.; Yokoyama, C.; et al. Enzymes and receptors of prostaglandin pathways with arachidonic acid-derived substrates and products. J. Biol. Chem. 2007, 282, 22254-22266.

114. Needleman, P.; Raz, A.; Minkes, M.S.; Ferrendelli, J.A.; Sprecher, H. Triene prostaglandins: Prostacyclin and thromboxane biosynthesis and unique biological properties. Proc. Natl. Acad. Sci. USA 1979, 76, 944-948.

115. Takano, T.; Clish, C.B.; Gronert, K.; Petasis, N.; Serhan, C.N. Neutrophil-mediated changes in vascular permeability are inhibited by topical application of aspirin-triggered 15-epi-lipoxin A4 and novel lipoxin B4 stable analogues. J. Clin. Invest. 1998, 101, 819-826.

116. Lee, T.H.; Mencia-Huerta, J.-M.; Shih, C.; Corey, E.J.; Lewis, R.A.; Austen, K.F. Characterization and biologic properties of 5,12-dihydroxy derivatives of eicosapentaenoic acid, including leukotriene $\mathrm{B}_{5}$ and the double lipoxygenase product. J. Biol. Chem. 1984, 259, 2383-2389.

117. Goldman, D.W.; Pickett, W.C.; Goetzl, E.J. Human neutrophil chemotactic and degranulating activities of leukotriene $\mathrm{B}_{5}\left(\mathrm{LTB}_{5}\right)$ derived from eicosapentaenoic acid. Biochem. Biophys. Res. Commun. 1983, 117, 282-288.

118. Serhan, C.N.; Hamberg, M.; Samuelsson, B. Lipoxins: novel series of biologically active compounds formed from arachidonic acid in human leukocytes. Proc. Natl. Acad. Sci. USA 1984, 81, 5335-5339.

119. Serhan, C.N. A search for endogenous mechanisms of anti-inflammation uncovers novel chemical mediators: missing links to resolution. Histochem. Cell Biol. 2004, 122, 305-321. 
120. Morin, C.; Sirois, M.; Echave, V.; Rizcallah, E.; Rousseau, E. Relaxing effects of 17(18)-EpETE on arterial and airway smooth muscles in human lung. Am. J. Physiol. Lung Cell Mol. Physiol. 2009, 296, L130-L139.

121. Tjonahen, E.; Oh, S.F.; Siegelman, J.; Elangovan, S.; Percarpio, K.B.; Hong, S.; Arita, M.; Serhan, C.N. Resolvin E2: Identification and anti-inflammatory actions: Pivotal role of human 5-lipoxygenase in resolvin E series biosynthesis. Chem. Biol. 2006, 13, 1193-1202.

122. Serhan, C.N.; Fredman, G.; Yang, R.; Karamnov, S.; Belayev, L.S.; Bazan, N.G.; Zhu, M.; Winkler, J.W.; Petasis, N.A. Novel proresolving aspirin-triggered DHA pathway. Chem. Biol. 2011, 18, 976-987.

123. Serhan, C.N.; Gotlinger, K.; Hong, S.; Lu, Y.; Siegelman, J.; Baer, T.; Yang, R.; Colgan, S.P.; Petasis, N.A. Anti-inflammatory actions of neuroprotectin D1/protectin D1 and its natural stereoisomers: Assignments of dihydroxy-containing docosatrienes. J. Immunol. 2006, 176, 1848-1859.

124. Schwarz, D.; Kisselev, P.; Chernogolov, A.; Schunck, W.-H.; Roots, I. Human CYP1A1 variants lead to differential eicosapentaenoic acid metabolite patterns. Biochem. Biophys. Res. Commun. 2005, 336, 779-783.

125. Arita, M.; Ohira, T.; Sun, Y.-P.; Elangovan, S.; Chiang, N.; Serhan, C.N. Resolvin E1 selectively interacts with leukotriene $\mathrm{B}_{4}$ receptor BLT1 and ChemR23 to regulate inflammation. J. Immunol. 2007, 178, 3912-3917.

126. Titos, E.; Rius, B.; González-Périz, A.; López-Vicario, C.; Morán-Salvador, E.; Martínez-Clemente, M.; Arroyo, V.; Clária, J. Resolvin D1 and its precursor docosahexaenoic acid promote resolution of adipose tissue inflammation by eliciting macrophage polarization toward an M2-like phenotype. J. Immunol. 2011, 187, 5408-5418.

127. Bannenberg, G.L.; Chiang, N.; Ariel, A.; Arita, M.; Tjonahen, E.; Gotlinger, K.H.; Hong, S.; Serhan, C.N. Molecular circuits of resolution: Formation and actions of resolvins and protectins. J. Immunol. 2005, 174, 4345-4355.

Samples Availability: Available from the authors.

(C) 2012 by the authors; licensee MDPI, Basel, Switzerland. This article is an open access article distributed under the terms and conditions of the Creative Commons Attribution license (http://creativecommons.org/licenses/by/3.0/). 